\title{
一酸化炭素とヒドロシランを用いる 新しい触媒反応群
}

\author{
村 井真 二*・園 田 昇*
A Series of New Catalytic Reactions with Carbon Monoxide and Hydrosilane.

Shinji MURAI* and Noboru SONODA*

\begin{abstract}
New catalytic reaction with carbon monoxide and hydrosilane is reviewed. The new reaction allows the conversion of various oxygen-containing compounds into products having one or two additional carbon atom(s) with the aid of cobalt carbonyl as a catalyst. Emphasis is laid on the understanding of the common elementary processes involved in apparently different catalytic transformations.
\end{abstract}

は じめに

Reppe 反応は水と一酸化炭素を反応試剤として用いる 触媒反応であり，また Roelen 反応（いわゆるオキソ反 応またはヒドロホルミル化反応) は水素と一酸化炭素を 反応試剤としている。前者の反応基質は主にアセチレン 類で種々のカルボン酸が合成され, 後者はオレフィンや 含酸素化合物を反応基質としこれらからアルデヒドやア ルコールが得られることは広く知られている。

われわれの研究室で最近ヒドロシラン $\left(\mathrm{HSiR}_{3}\right)$ と一酸 化炭素とを反応試剂とする新しい触媒反応が見い出され た。この新反応は, 40 年余の歴史を有し水や水素を反応 試剤とする Reppe 反応や Roelen (オキソ) 反応とは, 工業的重要性は比べるべくもない。しかし，ヒドロシラ ンと一酸化炭素を反応試剂とする新触媒反応は, 反応の 多様性という点ではこれらの著名な 2 つの応にはない 側面を有している。

ここでいう反応の多様性とは, 適用可能な反応基質の 幅, 生成物の種類, 反応基質と生成物との関係の多様性, および生成物の有機合成中間体としての有用性などの点 におけるものである。

われわれが, この新しい触媒反応を見い出した経緯は すでに 1979 年の総説で詳しく述べた ${ }^{1)}$ 。また, そこでは, オレフィンを反応基質とする反応, その反応機構の詳細,

* 大阪大学工学部石油化学科

* Department of Petroleum Chemistry, Faculty of Engineering, Osaka University,
若干の含酸素化合物を基質として用いた反応などを述べ, 新反応群が 4 種類の触媒サイクルの組み合わせから成る ことを示した。本稿では現在得られつつある知見を含め, 反応基質として含酸素化合物を用いた場合を中心に述べ る。さらに今回は, 一見複雑な多種類の反応に含まれて いる, 共通の素反応, 共通の中間体, 共通のプリンシプ ルの考察を行い, 各反応間の相互関係の理解に重点を置 $<。$

\section{1. $\mathrm{Co}_{2}(\mathrm{CO})_{8}$ 触媒・ $\mathrm{HSiR}_{3} \cdot \mathrm{CO}$ を用いる 触媒反応の概要}

本触媒反応に用いたヒドロシランは, 取り扱いの容易 さと生成物の NMR による解析の容易さの点からほとん どの場合ジェチルメチルシラン $\left(\mathrm{HSiEt}_{2} \mathrm{Me}, \mathrm{bp} 76^{\circ} \mathrm{C}\right.$, 水拉よび空気に対しきわめて安定, NMR でメチル基の シングレットが生成物の構造決定や純度の解析に便利) である。またこれらの反応はトリメチルシラン $\left(\mathrm{HSiMe}_{3}\right.$, $\left.\mathrm{bp} 9{ }^{\circ} \mathrm{C}\right)$ やトリエチルシラン $\left(\mathrm{HSiEt}_{3}, \mathrm{bp} 108^{\circ} \mathrm{C}\right)$ でも 同様に進行する。いずれのシランも市販品があり容易に 入手できる。これらを以下では $\mathrm{HSiR}_{3}$ と略記する。さら に表現の簡略化のため, 以下ではケイ素上の置換基とコ バルト上の配位子を省略することが多い。(一酸化炭素 も, 以下 $\mathrm{CO}$ と書く。)

$$
\begin{array}{ll}
\text { "HSi" }=\mathrm{HSiR}_{3} & \\
\text { "HCo" }=\mathrm{HCo}(\mathrm{CO}) \mathrm{nL} & \mathrm{n}=2 \text { or } 3, \mathrm{~L}=\mathrm{CO} \text { or } \mathrm{PPh}_{3} \\
\text { "SiCo" }-\mathrm{R}_{3} \mathrm{SiCo}(\mathrm{CO}) \overline{\mathrm{nL}} & \begin{array}{l}
\mathrm{n}=2 \text { or } 3, \mathrm{~L}=\mathrm{CO} \text { or } \mathrm{PPh}_{3} \\
\mathrm{R}_{3} \mathrm{Si}=\mathrm{MeEt}_{2} \mathrm{Si} \text { etc. }
\end{array}
\end{array}
$$




\section{1. 反応基質と生成物の概要 さて, $\mathrm{HSiR}_{3}$ と $\mathrm{CO}$} を反応試剂とし $\mathrm{Co}_{2}(\mathrm{CO})_{8}$ 触媒を用いる反応で，どんな ものが反応し何が得られるのか。これを一言で言い表わ すことのむずかしさが，とりもなおさず本反応の持つ多 様性を端的沅している。現在まで明らかになったとこ ろでは，反応基質としてはアルデヒド，アルキルアセテ 一ト, ラクトン, 環状エーテルなどの含酸素化合物とオ レフィン類が用い得る ${ }^{2)}$ 。これらの反応基質と, $\mathrm{CO} 1$ 分子または 2 分子, 掠よび $\mathrm{HSiR}_{3} 1 \sim 3$ 分子とが反応し 生成物を与える。得られる生成物は反応基質よりも炭素 数が 1 つないし 2 つ増し, この増加した炭素原子にシロ キシ基 $\left(-\mathrm{OSiR}_{3}\right)$ などが結合し, 様々な含酸素官能基と なる。本反応で導入される官能基の例を次に示す。

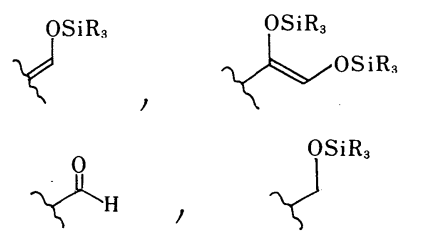

すなわち, $\mathrm{HSiR}_{3}$ と $\mathrm{CO}$ を用いる本触媒反応は, 含酸 素官能基の形成を伴なう新しい型の増炭反応と言える。 得られる生成物は, エノール，エンジオール， $\alpha$-ヒドロ キシアルデヒドなど通常不安定か生成困難な化合物の水
酸基がシリル基であらかじめ保護されている形とみなす ことができる。これらの化合物は, 種々の官能基変換反 応や炭素一炭素結合生成反応の出発物質となり得るので, 有用な有機合成中間体であるといえる。具体的な触媒反 応については次項以下で述べるが, 反応の 1 つの例とし てシクロヘキシルアセテートからのシクロヘキサンカル ボアルデヒドェノールのシリルエーテルへの触媒的変換 を式（1）に示す。反応はオートクレーブに，シクロへ キシルアセテート $(10 \mathrm{mmol}), \mathrm{HSiEt}_{2} \mathrm{Me}(30 \mathrm{mmol})$, $\mathrm{Co}_{2}(\mathrm{CO})_{8}(0.4 \mathrm{mmol})$, および溶媒としてベンゼン $(20$ $\mathrm{ml}$ ) を仕込み, $\mathrm{CO}$ 加圧 (室温初圧 $50 \mathrm{~kg} / \mathrm{cm}^{2}$ )下, 200 ${ }^{\circ} \mathrm{C}$ で 6 時間反応させる。生成物の収率は $75 \%$ である。 生成物中のオキシメチンン基が $\mathrm{CO}$ 由来である。

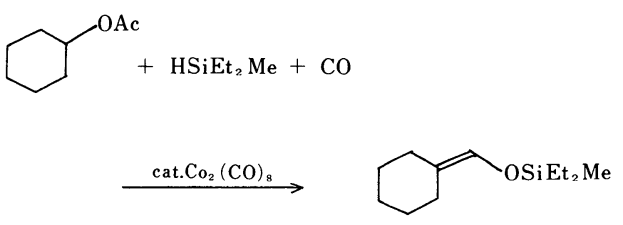

1. 2. 触媒活性種種々の含酸素化合物を反応基質 とし $\mathrm{CO}$ と $\mathrm{HSiR}_{3}$ を反応試剤, $\mathrm{Co}_{2}(\mathrm{CO})_{8}$ を触媒 (簃密 には触媒前駆体）とする反応で，最も重要な役割を果た 寸触媒活性種は, 触媒反応開始時に次の反応 (式 2 ) に
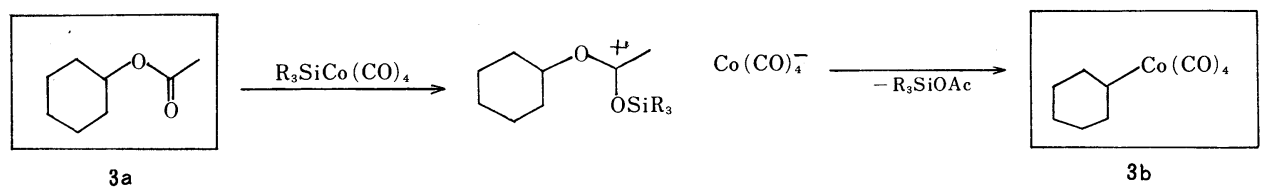

$3 \mathrm{~b}$<smiles>[R15]C(C(=O)OC(C)(C)C)C(=O)C1CCCCC1</smiles>
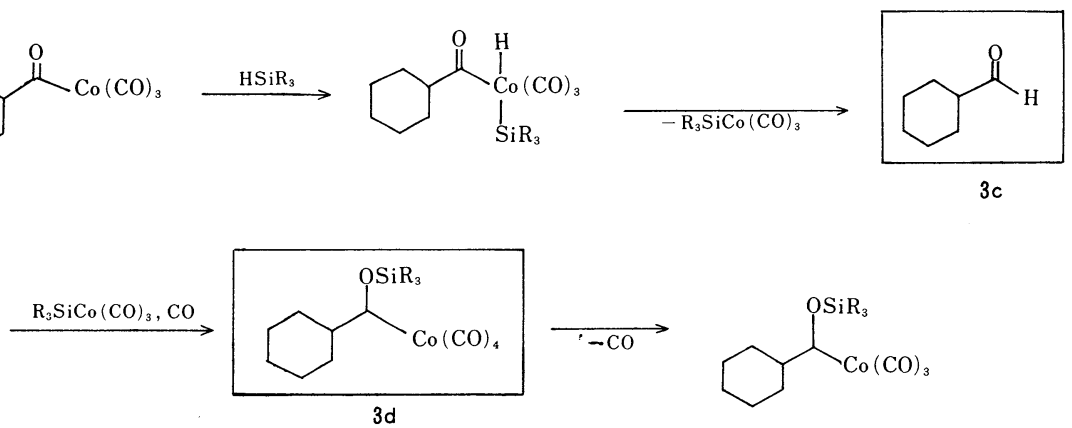<smiles>[R15]OC(C(=O)[O-])C1CCCCC1</smiles>

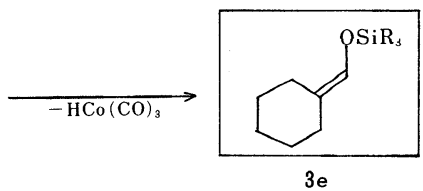

[regeneration of active catalyst : $\left.\mathrm{HCo}(\mathrm{CO})_{3}+\mathrm{CO}+\mathrm{HSiR}_{3} \underset{-\mathrm{H}_{2}}{\longrightarrow} \mathrm{R}_{3} \mathrm{SiCo}(\mathrm{CO})_{4}\right]$

Fig. 1 Mechanism of the catalytic reaction. (3a-3e correspond to those in Chart 1) 
より系中で生成する ${ }^{3)}$ シリルコバルトカルボニル, $\mathrm{R}_{3} \mathrm{SiCo}$ $(\mathrm{CO})_{4}$ ，であると考えられる。のとき副生する $\mathrm{HCo}(\mathrm{CO})_{4}$ $\mathrm{HSiR}_{3}+\mathrm{Co}_{2}(\mathrm{CO})_{8} \longrightarrow$

$$
\mathrm{HCo}(\mathrm{CO})_{4}+\mathrm{R}_{3} \mathrm{SiCo}(\mathrm{CO})_{4}
$$

は過剩の $\mathrm{HSiR}_{3}$ が存在すると水素を放ちやはり $\mathrm{R}_{3} \mathrm{SiCo}$ (CO) 4 に変換される(式 3 )。またこの式 (3) の反応は, 触 媒反応の最終段階で生成物の形成と同時に副生するコバル 卜錯体が "HCo" のとき，これを再び "SiCo" 亿変換し 触媒サイクルを再スタートさせる反応としても重要であ る。

$$
\mathrm{HCo}(\mathrm{CO})_{4}+\mathrm{HSiR}_{3} \longrightarrow \mathrm{R}_{3} \mathrm{SiCo}(\mathrm{CO})_{4}+\mathrm{H}_{2}
$$

このようにして系中で生成するシリルコバルトカルボ ニルが，反応基質である含酸素化合物と反応寸る結果， アルキルコバルト錯体を与えるという過程が，本触媒反 応の鍵ともいえる重要な部分である。具体的な例として 図 1 に,すでに式 (1) で示した反応の全経路を示す。この 例では反応基質であるアルキルアセテートのカルボニル 酸素がシリルコバルトのケイ素を攻撃し, そのエステル 部分が脱離基として活性化されるとともに $\mathrm{Co}(\mathrm{CO})_{4}-$ を 与える。ついで $\mathrm{Co}(\mathrm{CO})_{4}^{-}$の求核攻撃により炭素一酸素 結合が開裂したシクロヘキシルコバルト錯体 $3 \mathrm{~b}$ を与え る。3b はアルキルーアシル転位 (CO挿入), $\mathrm{HSiR}_{3}$ の酸 化的付加の後, 還元的脱離によりいったんアルデヒド $3 \mathrm{c}$ を中間体として与える。3c は $3 \mathrm{~d}$ を経て, $\mathrm{HCo}(\mathrm{CO})_{3}$ が $\beta$-脱離をし生成物 $3 \mathrm{e}$ となる。脱離した $\mathrm{HCo}(\mathrm{CO})_{3}$ は $\mathrm{HSiR}_{3}$ と $\mathrm{CO}$ と反応し(式 3 ), 元の触媒活性種であ るシリルコバルト錯体を再生する。

炭素一遷移金属結合の生成は，一酸化炭素を用いる増 炭反応に必須の過程である。Reppe 反応や Roelen (オキ ソ）反応では，金属ヒドリド (H-MLn) の不飽和結合へ の付加により，必要な炭素一遷移金属結合が生成する。 本触媒反応では，上の例で見たように(図 1, 3a $\rightarrow 3 b$ ), ケイ素一遷移金属結合を持つ触媒活性種の, ケイ素の高い 酸素親和性を利用して炭素一遷移金属結合を供給するとい う，新しい独特の方法論が基盤となっている。シリルコ バルト錯体 "SiCo" のケイ素中心のルイス酸性がきわめ

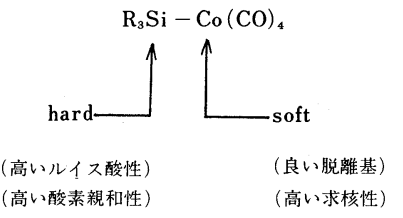

て高いことは, 別途単離された ${ }^{3,4)}$ この錯体と, アルコー $ル^{4 \mathrm{~b}, 5)} ， 3$ 級アミンやホスフィン6)，環状エーテル ${ }^{5,7)}$
などとの反応が示している。

1.3. 反応経路のパターン 本触媒反応の個々の結 果については後に詳しく示すが，ここでは各反応群から 代表的な例を選んで示すとともに，これらの反応に共通 のパターンを述べる。共通の反応形式を知ることにより, 一見複雑な反応群もいくつかの単純な規則により支配さ れていることが理解できる。さらに主な反応条件（反応 基質と $\mathrm{HSiR}_{3}$ のモル比, $\mathrm{CO}$ 圧, 温度) が与えられれば 反応結果の予測も, 現在ある程度可能となってきた。言 葉をかえれば，未知の新反応を設計することも可能とな りつつある。

チャート 1 に, $\mathrm{Co}_{2}(\mathrm{CO})_{8}$ を触媒とする種々の反応基 質とヒドロシランと一酸化炭素との反応の代表的な反応例 を示した。各反応間の相互の関係を理解しやすい上うに, 共通の中間体や共通の素反応が縦の同じ位置になるよう に配列した。従って, チャート1の見出しが本触媒反応 の共通のパターンを表わすことになる。たとえば, チャ ート 1 の反応 No. 3 は，すでに述べた図 1 のシクロへキ シルアセテートの反応機構を簡略化して示したものであ り，図 1 中, 枠で囲んだ構造式 $3 \mathrm{a} \sim 3 \mathrm{e}$ がチャート 1 の $3 a \sim 3 e$ に対応している。素反応や中間体のうち, 他の 触媒反応と比較するときの共通の要素を下に示す。

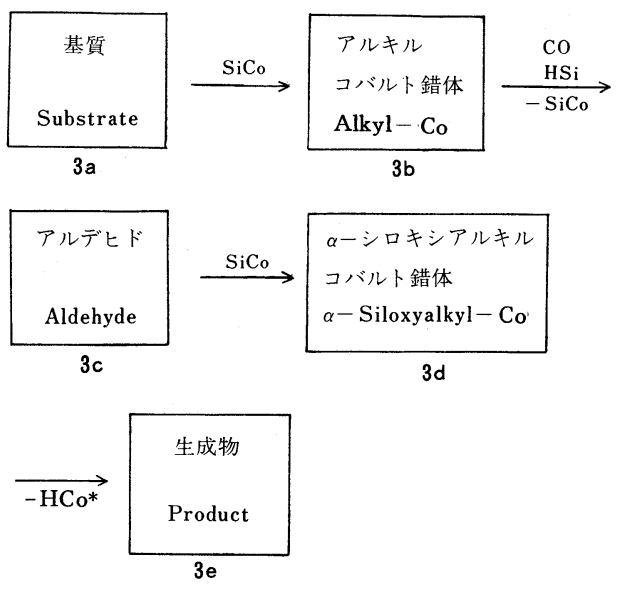

さて, チャート 1 に収録した反応は 10 種類（反応番 号 No.1 10) である。この他化，CO を用いない場合の アルデヒドの $\mathrm{Co}_{2}(\mathrm{CO})_{8}$ 触媒による $\mathrm{HSiR}_{3}$ との反応 (反 応番号 No.I と II) を参考のために示した。この10個の 反応のうち, 反応基質としては 5 種類が含まれており, No. 1 と 2, No. 5 7, No. 8 10 は同一の反応基質が, 異なる反応条件下ではそれぞれ異なる生成物を与える例 である。No. 3 から No.10 まで(但しNo. 4 は除く) はい ずれも，基質と "SiCo" の反応によるアルキルコバルト 
Chart $1 \mathrm{Co}_{2}(\mathrm{CO})_{8}$ - Catalyzed reaction of various substrates with $\mathrm{HSiEt}_{2} \mathrm{Me}$ and $\mathrm{CO}$,

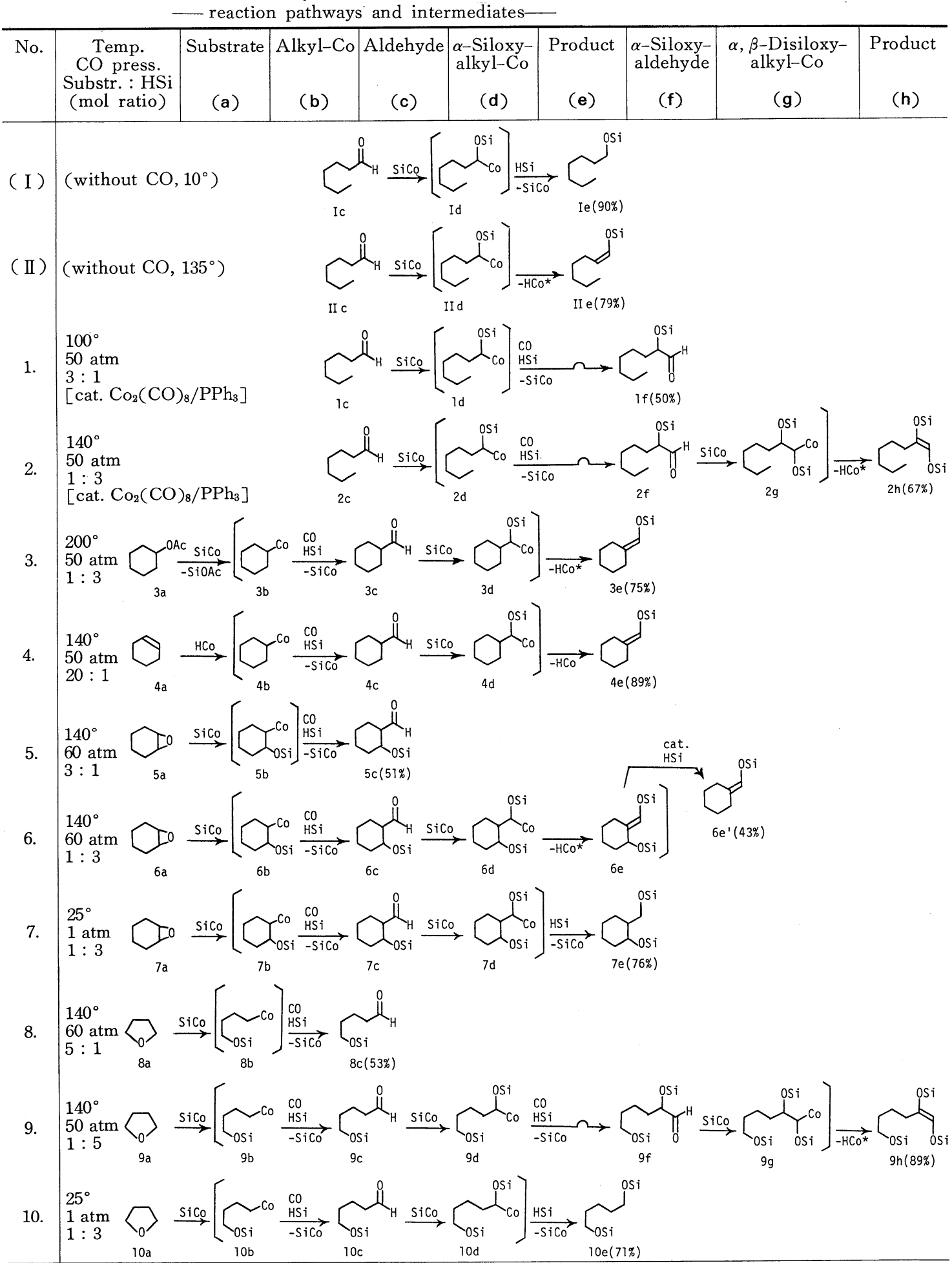

Yields are based on the limiting reactants (substrates or $\mathrm{HSi}$ ). ${ }^{*}$ ) $\mathrm{HCo}^{*}$ reacts with HSi to regenerate SiCo. 
錯体の生成を経て，基質がホルミル化されたアルデヒド を与えている。No. 4 の基質がオレフネンの場合には基 質と “HCo" の反応を経てアルデヒドが生成する。これ らのアルデヒド (c) は，そのままの形で生成物として単 離される場合 $(5 \mathrm{c}, 8 \mathrm{c})$ と, さらに反応し $\alpha$-シロキシア ルキルコバルト錯体 $(3 \mathrm{~d}, 4 \mathrm{~d}, 6 \mathrm{~d}, 7 \mathrm{~d}, 9 \mathrm{~d}, 10 \mathrm{~d})$ 一進 む場合とがある。この (d) の うち, $3 \mathrm{~d}, 4 \mathrm{~d}, 6 \mathrm{~d}$ は $\beta-\mathrm{H}$ 脱離により生成物 $(\mathrm{e})$ を与え, $7 \mathrm{~d}, 10 \mathrm{~d}$ は水素化されて 生成物 (e) を与える。9d はさらに CO と反応し第 2 の アルデヒド中間体 $9 \mathrm{f}$ を経て生成物 $9 \mathrm{~h}$ に至る。この反 応において $9 \mathrm{c}$ から $9 \mathrm{~h}$ までの過程は, アルデヒドを出 発物質とする No. 2 の反応の $2 \mathrm{c}$ から $2 \mathrm{~h}$ への過程と同 一である。やはりアルデヒドを出発物質とする反応No. 1 では, 反応 No. 9 の第 2 のアルデヒド中間体 $9 f$ に相当 する $1 \mathrm{f}$ が生成物として単離される。

チャート 1 をアルデヒド (c と $\mathrm{f}$ の欄)を中心に見ると 興味深い。アルデヒドは, ある場合には出発物質であり (1c，2c)，反応中間体であり $(2 \mathrm{f}, 3 \mathrm{c}, 4 \mathrm{c}, 6 \mathrm{c}, 7 \mathrm{c}, 9 \mathrm{c}$, $9 \mathrm{f}, 10 \mathrm{c})$ ，またある場合には生成物である(1f, $5 \mathrm{c}, 8 \mathrm{c})$ 。

つぎに，本触媒反応で種々の生成物がどのような要因 で決定されるかについて述べる。チャート1にそれぞれ の反応の反応条件を示したが，生成物決定の要因で重要 なものは，i）反応基質の構造，ii）反応基質とヒドロシ ランのモル比，iii）反応温度である。CO の圧力の影響 については, 現在まだ研究が進んでいない。まず, $\mathrm{CO}$ が 1 分子取り込まれたアルデヒドが生成物として得られる ためには，反応基質を $\mathrm{HSiR}_{3}$ に対し過剩に用いる必要 がある。これは触媒活性種である "SiCo"が，含酸素官 能基を有する反基質と, 生成物であるアルデヒドとの いずれとも反応可能であり，基質と " $\mathrm{SiCo}$ との反応が 優先する必要があるからである(反応No. 1, 5, 8)。次に $\beta-\mathrm{H}$ 脱離によりエノールエーテルが生成するためには, その前駆体が "HCo" の脱離に適した構造を持つことが 重要である。すなわち, 脱離すべきコバルト錯体のコバ ルトの $\beta$ 位がメチレンではなくメチン水素が望ましい。 チャート 1 において, $2 \mathrm{~g}, 3 \mathrm{~d}, 4 \mathrm{~d}, 6 \mathrm{~d}, 9 \mathrm{~g}$ はこれに相 当する。さらにこの “ $\mathrm{HCo}^{\prime}$ ”脱離は反応温度の高いとき に起り，7d ではコバルトの $\beta$-位がメチン水素であるに もかかわらず反応温度が低いので $\beta$-脱離は起らない。 また $2 \mathrm{~d}$ と $9 \mathrm{~d}$ はコバルトの $\beta$-位がメチレンであるため, 反応温度が高いにもかかわらず $\beta$-脱離は起らない。これ ら $2 \mathrm{~d}$ と $9 \mathrm{~d}$ には $\mathrm{CO}$ が插入し反応は $\beta$-脱離に適した 構造をもつ中間体 $(2 \mathrm{~g}$ や $9 \mathrm{~g})$ が現れるまで進むことに なる。反応温度が低く $\mathrm{CO}$ 圧が低いと, $\alpha$-シロキシアル キルコバルト錯体はヒドロシランにより水素化をうける
(II d, $7 \mathrm{~d}, 10 \mathrm{~d}$ )。

以上要約すれば，反応の開始段階では前項で述べたよ うに “SiCo" によるアルキルコバルト錯体の生成が重要で あり，また反応がどのような経路をたどるかについては, チャ ート1に示されるように，中間体である種々のコバルト 錯体から $\beta$-位の水素とコバルトが $\beta-H$ 脱離を行うか否 かが重要な因子であるといえよう。

\section{2. アルデヒドと $\mathrm{HSiR}_{3}$ と $\mathrm{CO}$ との反応}

前項で述べたように， $\mathrm{CO}$ のない系ではアルデヒドは $\mathrm{Co}_{2}(\mathrm{CO})_{8}$ 存在下 $\mathrm{HSiR}_{3}$ と反応し, 室温以下ではヒドロ シリル化が (チャート 1, No. I) $100{ }^{\circ} \mathrm{C}$ 以上では脱水素 ケイ素化 (チャート1, No. II) が主反応となる ${ }^{2 \mathrm{~g}}$ 。 $\mathrm{Co}_{2}$ $(\mathrm{CO})_{8}$ が, アルコール, カルボン酸, アミドの脱水素ケ イ素化の触媒となることが知られており ${ }^{5)}$ ，また桜井, 中平らにより, $\mathrm{Co}_{2}(\mathrm{CO})_{8}$ と 3 級アミンまたはホスフィン などの組み合わせが，ケトンと $\mathrm{HSiR}_{3}$ からエノールシリ ルエーテルを合成する脱水素ケイ素化の優れた触媒とな ることが報告されている8

アルデヒドと $\mathrm{HSiR}_{3}$ と $\mathrm{CO}$ との反応は, アルデヒド 過剰の系では $\alpha$-シロキシアルデヒドが (チャート 1, No. 1), $\mathrm{HSiR}_{3}$ 過剩の系ではさらに $\alpha-$ はロキシアルデヒドが 脱水素ケイ素化されたエンジオールジシリルエーテル （チャート1, No. 2) を与える。種々のアルデヒドについ

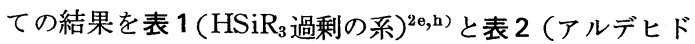
過剩の系 $)^{2 \mathrm{f}, \mathrm{h})}$ に示した。なおこれらの反応に限り $\mathrm{PPh}_{3}$ を $\mathrm{Co}_{2}(\mathrm{CO})_{8}$ とともに用いた。これは $\mathrm{PPh}_{3}$ を共存させ ない場合には, 所定の反応温度まで昇温している間にア

Table 1 Conversion of aldehydes to bis-siloxyalkene.

aldehyde

Reaction conditions ; aldehyde ( $30 \mathrm{mmol}), \mathrm{HSiEt}_{2} \mathrm{Me}(10 \mathrm{mmol})$, $\mathrm{Co}_{2}(\mathrm{CO})_{8}(0.4 \mathrm{mmol}), \mathrm{PPh}_{3}(0.4 \mathrm{mmol}), \mathrm{CO}(50 \mathrm{~atm}), \mathrm{C}_{6} \mathrm{H}_{6}(20$ $\mathrm{ml}), 100^{\circ}, 20 \mathrm{~h}$ 
Table 2 Conversion of aldehydes to $\alpha$-siloxyaldehyde

aldehyde

Reaction conditions ; aldehyde (10 mmol), $\mathrm{HSiEt}_{2} \mathrm{Me}(30 \mathrm{mmol})$, $\mathrm{Co}_{2}(\mathrm{CO})_{8}(0.4 \mathrm{mmol}), \mathrm{PPh}_{3}(0.4 \mathrm{mmol}), \mathrm{CO}(50 \mathrm{~atm}), \mathrm{C}_{6} \mathrm{H}_{6}(20$ $\mathrm{ml}), 140^{\circ}, 20 \mathrm{~h}$.

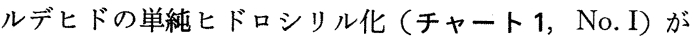
起ってしまうためである。( $\mathrm{PPh}_{3}$ 共存により, チャート 1 の $1 \mathrm{~d}$ や $2 \mathrm{~d}$ が配位不飽和となりにくく, 配位不飽和 錯体特有の $\beta$-脱離や $\mathrm{HSiR}_{3}$ の酸化的付加が抑えられる 結果, $\mathrm{CO}$ 插入が有利になるという効果も考え得る。し かしチャート1の $9 \mathrm{~d}$ から $9 \mathrm{f}$ への反応が $\mathrm{PPh}_{3}$ の共存 がなくても起っているので，この効果は決定的なもので はない。)

これらのアルデヒドのホルミル化反応で注目に值する 点は，筆者らの知る限り，この反応がカルボニル基のカ ルボニル炭素上で，CO を用いてカルボニル化が触媒的 に生起する最初の明快な反応例となっている点であろう。 アルデヒドに対するこの型の反応は，Fischer-Tropsch 反応 ${ }^{9)}$ やUnion Carbide 社 (UCC) のエチレングリコー ル合成 ${ }^{10)}$ など CO を用いる反応に関連して重要と見なさ

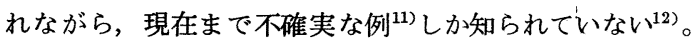

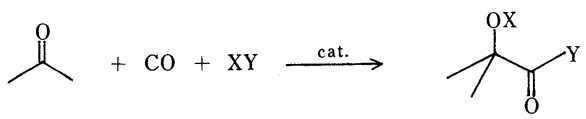

この理由は, カルボニル基と何らかの触媒種との反応で, $\mathrm{CO}$ 挿入に必要な炭素一遷移金属結合生成の，適当な手 段がこれまで知られていなかったためであろうと考えら れる。本触媒反応では, 触媒活性種 "SiCo" とカルボニ ル基との反応で，ヶイ素の酸素に対する大きな親和性が
炭素一遷移金属結合形成を強制するという，新しい方法 論が新反応の実現に結びついたものと考えられる。

$$
\text { }
$$

$\alpha$-ヒドロキシアルデヒドは合成化学上有用な化合物で あるが，アルデヒドから炭素を1つ増してこれを得るこ とは通常容易ではなく, このため種々のホルミルアニオ ン等価体が工夫されている13)。またエンジオールジシリ ルエーテル ${ }^{14)}$ む, ヘテロ環 ${ }^{14 a)}$, ジカルボニル化合物 ${ }^{14,15)}$, 置換アシロイン ${ }^{14,15 a, 16)}$ などの合成中間体としての利用 価值が高く，これまではエステルの縮合による合成法 ${ }^{14)}$ など17)が知られているが，これらの方法の欠点は対称に 置換されたエンジオールジシリルエーテルのみしか合成 できないことにある。本触媒反応はこれらの有用な合成 中間体の有効な手段となり得るものと思われる。

\section{3. エステルの反応}

3. 1. アルキルアセテートと $\mathrm{HSiR}_{3}$ と $\mathrm{CO}$ との反応 すでに図 1 とチャート 1 の No. 3 に示したようにシク ロヘキシルアセテートは炭素数の 1 つ増加したアルデヒ ドェノールのシリルエーテルを与える。同様に 2 級アル

Table 3 Reaction of sec-ROAc with $\mathrm{HSiR}_{3}$ and CO.

alkyl acetate

Reaction conditions ; ROAc $(10 \mathrm{mmol}), \mathrm{HSiR}_{3}(30 \mathrm{mmol}), \mathrm{CO}(50$ atm $), \mathrm{Co}_{2}(\mathrm{CO})_{8}(0.4 \mathrm{mmol})$, in $\mathrm{C}_{6} \mathrm{H}_{6}(20 \mathrm{ml}), 200^{\circ}, 6 \mathrm{~h}$ 
キルアセテートから種々のエノールシリルエーテルが良い 収率で合成できる ${ }^{21)}$ 。結果を表 3 に示した。

1 級アルキルアセテートを反応基質として用いたとき には, 表 3 の生成物に相当するエノールシリルエーテル とともに, 一酸化炭素が 2 分子取り込まれたエンジオー ルジシリルェーテルが生成し，反応の選択性は良くない (チャート1中の生成物記号で下に示す)。この反応の中

$$
\curvearrowright \mathrm{OAc} \longrightarrow \mathrm{II} \mathrm{e}+2 \mathrm{~h}
$$

間体は $2 \mathrm{~d}$ と同じであり，コバルトの $\beta$-位がメチン水素 でないため, 一部反応が 2 hまで進むものと考えられる。 なお 3 級アルキルアセテートでは，単に脱酢酸の起った オレフィンを与えるのみで CO は取り込まれない。3 級 アルキルコバルト錯体が生成しないか, 生成しても不安 定で $\mathrm{CO}$ 挿入は起らず $\beta-\mathrm{H}$ 脱離するためと考えられる。

一般にエノールシリルエーテルは, 非常に多彩な合成 化学的変換の可能な官能基であるが18), ほとんどの場合 カルボニル化合物を出発基質として合成されている。本 触媒反応で非カルボニル化合物からこの有用な合成中間 体が得られることは意義あるものと考えられる。本反応 は見方によってはアセトキシ基の，ひいては水酸基に対 するオキシメチレン化である。一般に，アルコキシメチ レン基は 4 級炭素中心を形成するための最も重要な中間 体であり，このためWittig 系試薬の利用など種々の工 夫がなされているが，出発基質はカルボニル化合物に限 られる ${ }^{19)}$ 。またこの方法でアルコキシメチレン基よりも 反応性が高く利用価値の多いシロキシメチレン基の導入 が試みられているが成功していなく $\left.{ }^{19 b}, \mathrm{c}\right)$, 別ルート多段 階を要するシロキシメチレン化の報告があるのみであ $る^{20)}$ 。

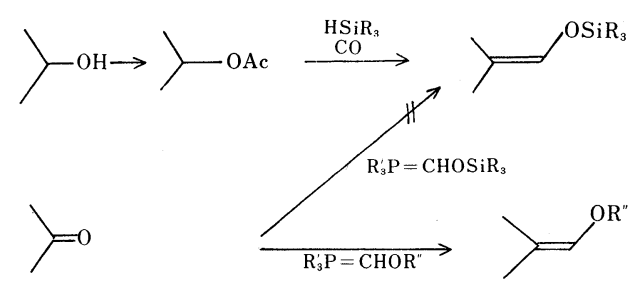

3.2. ラクトンと $\mathrm{HSiR}_{3}$ と $\mathrm{CO}$ との反応分子内エ ステルであるラクトンはアルキルアセテートと同様に反 応する ${ }^{1 \mathrm{i})}$ 。アルキルアセテートの反応ではアセトキシ基 はシリル酢酸 $\left(\mathrm{R}_{3} \mathrm{SiOAc}\right)$ として脱離したが，ラクトン では生成物中にシリルエステル部分として残る。触媒量 のピリジンを共存させることにより反応温度を下げ得る ことがわかった。ピリジンの共存がエノールシリルエー
Table 4 Reaction of lactones with $\mathrm{HSiR}_{3}$ and $\mathrm{CO}$.

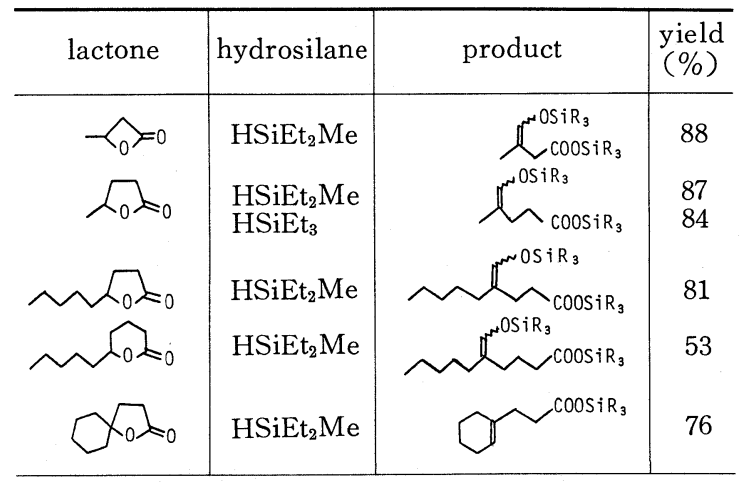

Reaction conditions ; lactone (10 mmol), $\mathrm{HSiR}_{3}$ ( $\left.30 \mathrm{mmol}\right), \mathrm{CO}$ (50 atm), $\mathrm{Co}_{2}(\mathrm{CO})_{8}(0.4 \mathrm{mmol})$, pyridine $(2.0 \mathrm{mmol}), \mathrm{C}_{6} \mathrm{H}_{6}(20 \mathrm{ml})$, $140^{\circ}, 6 \mathrm{~h}$

テル生成を助けることは，桜井，中平らによるヶトンか らのエノールシリルエーテルの合成の際に認められてい $3^{8)}$ 。ラクトンのアルコール部が 3 級のときは, アルキ ルアセテートの場合と同様に CO の関与しないオレフィ ンが生成する。結果を表 4 に示した。

\section{4. オレフィンの反応}

すでに述べたように $\mathrm{HSiR}_{3}$ と $\mathrm{Co}_{2}(\mathrm{CO})_{8}$ との反応は 2 種の触媒活性種 " $\mathrm{HCo}$ ” " $\mathrm{SiCo}$ ”を与える（式 2 )。 この "HCo" はオレフィンと反応しアルキルコバルト錯 体を与える。チャート1の反応No. 3 と No. 4 を比べる と，オレフィンの反応は，アルキルアセテートの反応と 同じ過程をたどり同じ生成物を与えることがわかる。し かもオレフィンの反応では, 生成物を与える過程で脱離 する "HCo" がそのまま触媒活性種が再生した形となる。

Table 5 Reaction of olefins with $\mathrm{HSiEt}_{2} \mathrm{Me}$ and $\mathrm{CO}^{\mathrm{a}}$.

\begin{tabular}{l|c|c}
\hline olefin & product & yield (\%) \\
\hline
\end{tabular}

a) Reaction conditions ; olefin ( $30 \mathrm{mmol}), \mathrm{HSiEt}_{2} \mathrm{Me}(10 \mathrm{mmol})$, $\mathrm{Co}_{2}(\mathrm{CO})_{8}(0.2 \mathrm{mmol}), \mathrm{CO}(80 \mathrm{~atm}), 140^{\circ}, 20 \mathrm{~h}$, in $\mathrm{C}_{6} \mathrm{H}_{6}(20 \mathrm{ml})$. b) olefin $(200 \mathrm{mmol}), \mathrm{Co}_{2}(\mathrm{CO})_{8}(0.4 \mathrm{mmol}), \mathrm{CO}(50 \mathrm{~atm})$. 
活性種 "HCo" はオレフィンと反応するか，式（3）に 従い HSi と対応寸るかの競争反応となり, $\mathrm{HSiR}_{3}$ 過㮃 の反応条件では，"HCo" はすべて "SiCo" に変換されて しまい触媒反応は止ってしまう。“SiCo” はオレフィンの ヒドロシリル化の触媒とはならないことは既に知られて いる3a)。結果を表 5 亿示寸1,2a c)。

オレフィンの反応では, $\mathrm{Co}_{2}(\mathrm{CO})_{8}$ のみならず, $\mathrm{Ru} や$ $\mathrm{Rh}$ 錯体も触媒活性を有することが明らかとなっている 2c)。オレフィンの反応機構の中間体にやはりアルデヒド が介在すること文を考えると, Ru や Rh 系触媒によって も含酸素化合物の $\mathrm{HSiR}_{3}$ と $\mathrm{CO}$ との反応が起り得ると 思われ，新触媒の開発は今後の重要な課題の 1 つである。

\section{5. 環状エーテルと $\mathrm{HSiR}_{3}$ と $\mathrm{CO}$ との反応}

5.1. CO 加圧下の反応 すでに述べたアルデヒド の反応でアルデヒドを $\mathrm{HSiR}_{3}$ に対し過剩に用いれば $\alpha$ ヒドロキシアルデヒドが得られる場合（表 2) と同様に, $\mathrm{CO}$ 加圧下環状エーテルを $\mathrm{HSiR}_{3}$ に対して過剩に用い反 応を行うと, 開環生成物である $\omega$-シロキシアルキルア ルデヒドが得られる2d 。シクロへキセンオキシドとテト ラヒドロフランの結果はチャート 1 の No. 5 と No. 8 に それぞれ示した。シクロヘキセンオキシドの場合, 生成

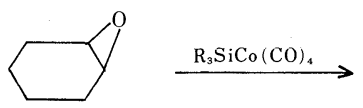

$5 a$

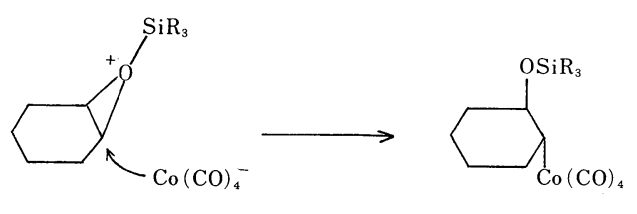

$5 b$
物 $5 \mathrm{c}$ はトランス体であり，このことから $5 \mathrm{a}$ と"SiCo" との反応は図 2 に示すように，シリルオキソニウムイオ ンの $\mathrm{Co}(\mathrm{CO})_{4}^{-}$によるトランス開環を含んでいるものと 考えられる。4員環エーテルのオキセタンも同様にアル デヒドを与えた $(\text { 式 } 4)^{2 \mathrm{j})}$ 。

$\mathrm{CO}$ 加圧下過鄱の $\mathrm{HSiR}_{3}$ と環状エーテルを反応させる と反応はさらに進む。たとえばテトラヒドロフランでは チャート 1 の No. 9 に示すように中間体が $\beta$-脱離に適 する構造（コバルトの $\beta$-位がメチン水素となる $9 \mathrm{~g}$ )を 持つまで進み，その結果エンジオールジシリルエーテル $9 \mathrm{~h}$ が生成する ${ }^{2 \theta)}$ 。オキセタンも同様な結果を与える $(\text { 式 } 4)^{2 \mathrm{j})}$ 。ところがシクロヘキセンオキシドの $\mathrm{HSiR}_{3}$ 過

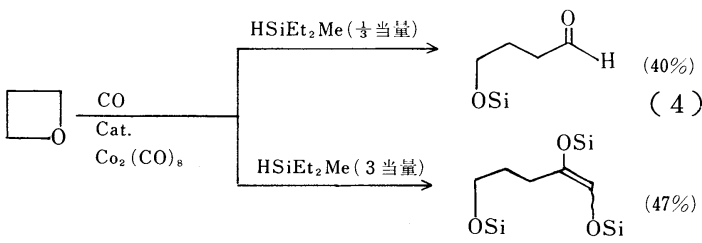

剩の系での反応 (チャート1，No.6) は，中間体である $\alpha$-シクキシアルキルコバルト $6 \mathrm{~d}$ の段階ですでにコバ ルトの $\beta$-位にメチン水素があり $\beta$-脱離で $6 \mathrm{e}$ を,さらに これが系中で還元され $6 \mathrm{e}^{\prime}$ を与える。

5.2. 常圧 CO による反応環状エーテルは, 常圧 - 常温付近という温和な条件下でも $\mathrm{Co}_{2}(\mathrm{CO})_{8}$ 存在下 $\mathrm{HSiR}_{3}$ と $\mathrm{CO}$ と反応することが明らかとなってきた ${ }^{2 \mathrm{k}) 。}$ 反応例をチャート 1 の No. 7 と No. 10 にあげたが，CO が常圧で反応温度が低いと $7 \mathrm{~d}$ や $10 \mathrm{~d}$ から $\mathrm{CO}$ 挿入や $\beta$ $\mathrm{H}$ 脱離は起らず，かわりに水素化され， $7 \mathrm{e} や 10 \mathrm{e}$ のよ らに開環シロキシメチル化された生成物が得られる。3 〜 6員環の無置換環状エーテルについて得られた結果を 表 6 亿示した。本触媒反応は， $\mathrm{CO}$ の風船を用い普通の フラスコで簡単に反応できること, 形式的には求核的才 キシメチル化といら通常達成困難な型211 の反応であるこ

Table 6 Reaction of cyclic ethers with $\mathrm{HSiEt}_{2} \mathrm{Me}$ and $\mathrm{CO}(1 \mathrm{~atm})^{\mathrm{a})}$.

\begin{tabular}{|c|c|c|c|c|c|}
\hline ether & solvent & temp. $\left({ }^{\circ} \mathrm{C}\right)$ & time $(\mathrm{h})$ & product & yield $(\%)$ \\
\hline$\nabla_{0}$ & $\mathrm{C}_{6} \mathrm{H}_{6}$ & 25 & 20 & & 90 \\
\hline & $n$-hexane & 25 & 7 & & 96 \\
\hline & $\mathrm{CH}_{2} \mathrm{Cl}_{2}$ & 25 & 20 & & 86 \\
\hline & $\mathrm{C}_{6} \mathrm{H}_{6}$ & 70 & 40 & & 44 \\
\hline
\end{tabular}

a) cyclic ether $/ \mathrm{HSi} \equiv / \mathrm{Co}_{2}(\mathrm{CO})_{8}=10 / 30 / 0.4(\mathrm{mmol}), \mathrm{CO}(1 \mathrm{~atm})$; yields are based on the cyclic ethers. 
Table 7 Reaction of tetrahydrofuranes with $\mathrm{HSiEt}_{2} \mathrm{Me}$ and $\mathrm{CO}(1 \mathrm{~atm})^{\mathrm{a})}$.

\begin{tabular}{|c|c|c|c|c|}
\hline \multirow{2}{*}{ run } & \multirow{2}{*}{$\begin{array}{l}\text { temp. } \\
\text { time }\end{array}$} & \multirow{2}{*}{$\begin{array}{l}\text { yield } \\
(\%)\end{array}$} & \multicolumn{2}{|c|}{ products } \\
\hline & & & cleavage at $1^{\circ}$ carbon & cleavage at $2^{\circ}$ or $3^{\circ}$ carbon \\
\hline 1 & $\begin{array}{l}60^{\circ} \\
20 \mathrm{~h}\end{array}$ & 85 & $\equiv \mathrm{Si}_{(100)}$ & \\
\hline 2 & $\begin{array}{l}40^{\circ} \\
20 \mathrm{~h}\end{array}$ & 77 & $\equiv$ Si $^{\prime} 0=\underbrace{}_{(75)}$ & 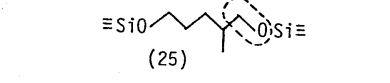 \\
\hline 3 & $\begin{array}{l}60^{\circ} \\
60 \mathrm{~h}\end{array}$ & 95 & & $\begin{array}{l}\operatorname{si0} \\
(80)\end{array}$ \\
\hline 4 & $\begin{array}{l}25^{\circ} \\
20 \mathrm{~h}\end{array}$ & 83 & & \\
\hline 5 & $\begin{array}{l}25^{\circ} \\
20 \mathrm{~h}\end{array}$ & 84 & $\equiv \underbrace{}_{(100)}=$ & \\
\hline 6 & $\begin{array}{l}60^{\circ} \\
20 \mathrm{~h}\end{array}$ & 81 & $\equiv \mathrm{Si}_{1}^{\prime} 0 \mathrm{~N}_{(100)}$ & \\
\hline
\end{tabular}

a) Incorporated $\mathrm{CO}$ is marked with broken circle. Reaction conditions; R-THF (10 mmol), $\mathrm{HSiEt}_{2} \mathrm{Me}(30 \mathrm{mmol})$, $\mathrm{Co}_{2}(\mathrm{CO})_{8}(0.4-1.6 \mathrm{mmol}), \mathrm{CO}(1 \mathrm{~atm})$, in $\mathrm{C}_{6} \mathrm{H}_{6}$.

と，コバルト触媒ではほとんど前例のない22)常圧 CO に よる反応であること, などの特徴を有している。

置換基の反応経路におよぼす影響を知るため, いくつ かの置換テトラヒドロフランの反応を検討した(表 7 )。 反応中心が 3 級 $>1$ 級 $>2$ 級の順に反応性が低下する (表 7, run 2 と 3)。従って反応中心上のメチル基の数が 増すとともに, シリルオキソニウムイオンでの C-O 結合の 開裂機構が，SN2 性から SN1 性へ移行するものと考え られる(図3)。この考えに従い，2-メチルテトラヒドロ
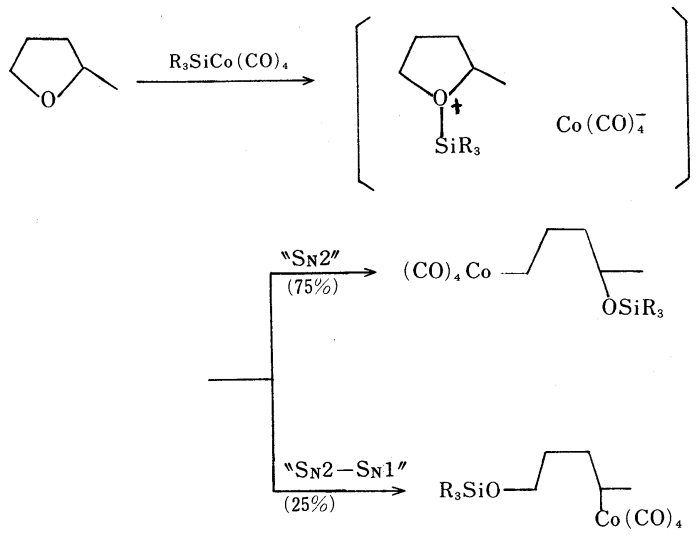

Fig. $3 \mathrm{SN} 2$ and $\mathrm{SN} 1$ character in $\mathrm{C}-\mathrm{O}$ bond cleavage.
フランの 2 位のメチル基上に電子吸引基をつけると（表 7, run 6) 2 位での開環は全く見られなくなる。この電 子的効果による反応の選択性の制御に加えて, 立体的効 果による選択性の制御も可能である（表 7, run. 4 と 5) ことは興味深い。なお 3 級中心が開裂した場合, これま でと同様にCO の取り込みは起らない(表 7, run. 3)。

\section{6. 関連する諸反応}

本触媒反応をよりよく理解し，またその応用と展開を はかるに際し, 重要な関連反応について簡単に述べる。 本反応が $\mathrm{HSiR}_{3}$ と $\mathrm{CO}$ の活性化を含み，また $\mathrm{HSiR}_{3}$ と $\mathrm{H}_{2}$ との反応性が類似している らヒドロシリル化反応 ${ }^{23}$ や Roelen 反応 (いわゆるオキ ソ反応 $)^{24)}$ と本反応には共通する素反応が多い。また, すでに述べたように, 本反応の触媒活性種 "SiCo" は soft 基と hard 基の組み合わせからなっているので, "SiCo" の反応挙動は, 近年活発に研究されている $\mathrm{Me}_{3} \mathrm{SiX}^{25)}(\mathrm{X}$ は I, CN, SR, SeR などの soft 基)などのそれと類似し ている。とくに, " $\mathrm{SiCo}$ と $\mathrm{Me}_{3} \mathrm{SiI}^{26)}$ の反応挙動は酷 似しており（例を図4に示す）参考となるところが大き い。これまで示してきた本反応の例は, 活性種 "SiCo" の $\mathrm{Co}(\mathrm{CO})_{4}^{-}$の部分を「 soft なホルミルアニオン等価体」 と読み変え得ることを示しており，この点にも合成化学 上の新方法論としての意義があるむのと考えられる。さ 

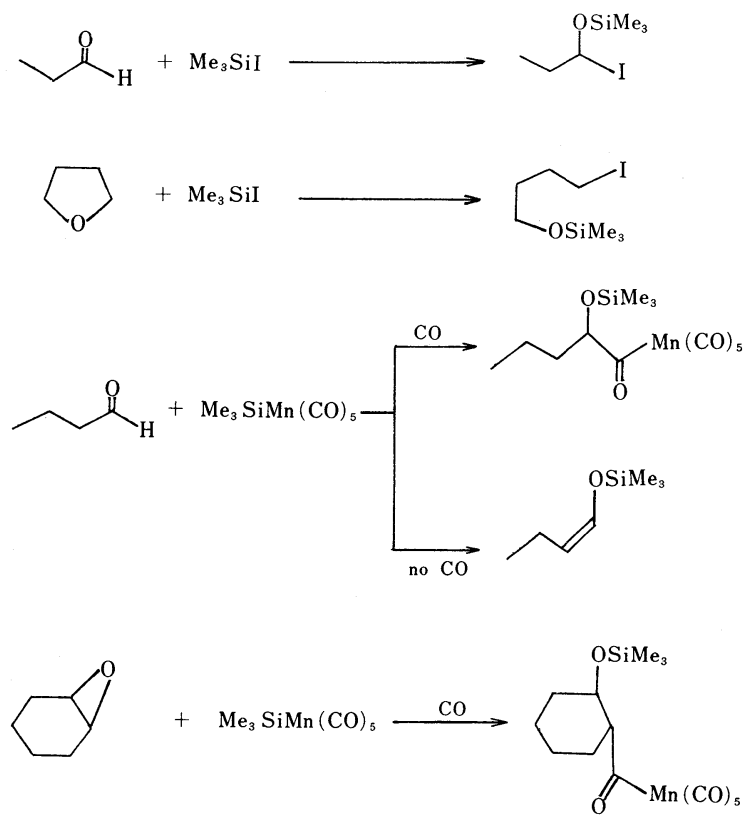

Fig. 4 Reactions of $\mathrm{Me}_{3} \mathrm{SiX}$ with oxygenates.

らに, 最近 Gladysz らは, $\mathrm{Me}_{3} \operatorname{SiMn}(\mathrm{CO})_{5}$ と含酸素化 合物との量論反応を行い，筆者らが示してきた反応機構 の妥当性を次々と裏ゔけつつある(例を図4 亿示す $)^{27) 。 ~}$

$$
\text { おわりに }
$$

以上，現在まで得られた結果を，反応相互間の関係に 重点を执いて述べた。今後に残された課題は多い。たと えば, 反応基質の拡大, 合成反応としての精密化と応用, 第 3 物質共存系での反応，新しい反応パターンの開発， 新しい触媒の開発，化学量論的反応の検討，などのいず れもが今後の発展に結びつくものと期待される。

筆者らの考えの誤りや，気付いていない点が多いこと と思われる。ぜひご教示とご批判を賜わりたい。なお, 本研究に用いたシラン類の原料は信越化学工業 (株) の ご厚意によるものである。記して謝意を表したい。

(昭和 55 年 11 月 11 日受理)

\section{文献}

1) S. Murai, N. Sonoda, Angew. Chem., 91, 896 (1979) ; ibid., Int. Ed. Engl., 18, 837 (1979)

2a) Y. Seki, A. Hidaka, S. Murai, N. Sonoda, ibid., 89, 196 (1977) ; ibid., Int. Ed. Engl., 16, 174 (1977)

b) Y.Seki, A. Hidaka, S. Makino, S. Murai, N. Sonoda, J. Organomet. Chem., 140, 361 (1977) c) Y.Seki, S. Murai, A. Hidaka, N. Sonoda, Angew. Chem., 89, 919 (1977) ; ibid., Int.Ed. Engl., 16, 881 (1977)

d) Y. Seki, S. Murai, I. Yamamoto, N. Sonoda, ibid., 89, 818 (1977) ; ibid., Int. Ed. Engl., 16, 789 (1978)

e) Y.Seki, S. Murai, N. Sonoda, ibid., 90, 139 (1978) ; ibid., Int. Ed. Engl., 17, 119 (1978)

f) S. Murai, T. Kato, N. Sonoda, Y. Seki, K. Kawamoto, Angew. Chem., 91, 421 (1979); ibid., Int. Ed. Engl., 18, 393 (1979)

g) 村井, 関, 加藤, 上利, 園田, 日本化学会第 37 春 季年会 (東京) 講演要旨集, 1 L48 (1978)

h) 村井, 加藤, 園田，末発表

i）茶谷, 村井, 園田, 有機合成総合研究発表講演会 (東京) 要旨集 p.83 (1980)

j）関，村井(利昭)，村井，園田，末発表

k) 土岐, 村井, 園田, 日本化学会第 42 秋季年会 (仙 台）講演要旨集，特 3 F 05 (1980); 畑山，土岐， 村井(利昭), 村井, 園田, 第 27 回有機金属化学 討論会(東京) 講演要旨集, B 114 (1980)；およ び末発表データ

3a) A. J. Chalk, J. F. Harrod, J. Am. Chem. Soc., 89, 1640 (1967)

b) Y. L. Baay, A. G. MacDiarmid, Inorg. Chem., 8, 986 (1969)

4a) D. L. Morrison, A. P. Hagen, Inorg. Synth, 13 , 65 (1972)

b) L. H. Sommer, J. E. Lyons, H. Fujimoto, J. Am. Chem. Soc., 91, 7051 (1969)

5) A. J. Chalk, Chem. Commun., 1970, 847

6a) H. G. Ang, P. T. Lau, Organomet. Chem. Rev., A8, 235 (1972)

b) C. S. Cundy, R. M. Kingston, M.F. Lappert, Adv. Organomet. Chem, 11, 253 (1973)

7) W. H. Ingle, G. Preti, A. G. MacDiarmid, J. Chem. Soc., Chem. Commun., 1973, 497 ; B. K. Nicholson, B. H. Robinson, J. Simpson, J. Organomet. Chem., 66, C 3 (1974) ; B. K. Nicholson, J. Simpson, ibid., 155, 237 (1978)

8) H. Sakurai, K. Miyoshi, Y. Nakadaira, Tetrahedron Lett., 1977, 2671

9a) G. Henrici-Olivé, S. Olivé, Angew. Chem., 88, 144 (1976) ; ibid., Int. Ed. Engl., 15, 136 . (1976)

b) C. Masters, Adv. Organomet. Chem., 17, 61 (1979)

10) R. L.Pruett, Ann. N. Y. Acad. Sci., 295, 239 (1977)

11) T. Yukawa, H. Wakamatsu, B. P., 1408857 (1974) ; S. K. Bhattacharyya, S. K. Palit, A. D. Das, Ind. Eng. Chem. Prod. Res. Dev., 9, 92 (1970) ; 化学量論的反応の例, J. A. Roth, M. Orchin, J. Organomet. Chem., 172, C 27 (1979)

12）溝呂木 勉, 触媒, 19, 90 (1977) 
13a) O. W. Lever, Jr., Tetrahedron, 32, 1963 (1976)

b) D. Seebach, Angew. Chem., 91, 259 (1979); ibid., Int. Ed. Engl., 18, 239 (1979)

c) M.Schlosser, Z. Brich, Helv. Chim. Acta, 61, 1903 (1978)

14a) K. Rühlmann, Synthesis, 1971, 236

b) J. J. Bloomfield, D. C. Owsley, J. M. Nelke, Org. React., 23, 259 (1976)

15a) J. Strating, S. Reiffers, H. Wynberg, Synthesis, 1971, 209, 211

b) Y. Ito, S. Fujii, T. Saegusa, J. Org. Chem., 41, 2073 (1976)

c) M. F. Semmelhack, B. P. Chong, L. D. Jones, J. Am. Chem. Soc., 94, 8629 (1972)

16) T. Wakamatsu, K. Hashimoto, M. Ogura, Y. Ban, Synth. Commun., 8, 319 (1978)

17) S. Murai, I. Ryu, Y. Kadono, H. Katayama, K. Kondo, N. Sonoda, Chem. Lett., 1977, 1219 ; D. R. Anderson, T.H. Koch, J. Org. Chem., 43, 2726 (1978) ; M. T. Reetz, G. Neumeier, Chem. Ber., 112, 2209 (1979)

18) J.K. Rasmussen, Synthesis, 1977, 91

19a) E. Wenkert, Acc. Chem. Res., 13, 27 (1980)

b) S. F. Martin, G. W. Phillips, T. A. Puckette, J. A. Colapret, J. Am. Chem. Soc., 102, 5866 (1980)

c) A. F. Kluge, I. S. Cloudsdale, J. Org. Chem., 44, 4847 (1979)
20) E. J. Corey, M. A. Tius, J. Das, J. Am. Chem., Soc., 102, 1742 (1980)

21) M. W. Rathke, R. Kow, J. Am. Chem. Soc., 94, 6854 (1972) ; D. Seebach, N. Meyer, Angew. Chem., 88, 484 (1976); ibid., Int. Ed. Engl., 15, 438 (1976) ; N. Meyer, D. Seebach, Chem. Ber., 113, 1290 (1980); H. Paulsen, E. Sumfleth, V. Sinnwell, N. Meyer, D. Seebach, ibid., 113, 2055 (1980)

22) J. J. Brunet, C. Sidot, B. Loubinoux, P. Caubee, J. Org. Chem., 44, 2199 (1979)

23) J.L.Speier, Adv. Organomet. Chem. 17, 407 (1979)

24) R.L.Pruett, ibid., 17, 1 (1979)

25) G. M. Rubottom, J. Organometal. Chem. Library, 10, 277 (1980)

26) M. E. Jung, A. B. Mossman, M. A. Lyster, J. Org. Chem., 43, 3698 (1978) ; M. E. Jung, M. A. Lyster, ibid., 42, 3761 (1977)

27) J.A. Gladysz, D. L. Johnson, J. Am. Chem. Soc., 101, 6433 (1979) ; idem, ibid., in press ; K. C. Brinkman, J. A. Gladysz, Chem. Commun., in press ; A. J. Blakeney, K. C. Brinkman, J. A. Gladysz, 2nd Chem. Congr. N. Amer. Contiment, Abstr. ORGN 204, San Francisco, Calif. (Las Vegas, Nev.), Aug. (1980)

\section{『有機合成化学協会誌』合本用ファイル}

「有機合成化学協会誌」合本ファイル 1 部に 1 カ年分 ( 12 冊) がとじられるようになっています。 合本ファイル 1 部 500 円 (送料実費下表参照)の上，前金にてお申込み下さい。

小包料金表

（昭和 55 年 10 月 1 日送料改訂実施）

\begin{tabular}{|c|c|c|c|c|c|}
\hline 地 帯 別 & 地 帯 別都 道 府 県 名 & $\begin{array}{l}1 \sim 4 \text { 部 } \\
1 \mathrm{~kg} \text { ま }\end{array}$ & $\begin{array}{l}5 \sim 9 \text { 部 } \\
2 \sim \mathrm{kg} \text { まで }\end{array}$ & $\begin{array}{l}10 \sim 14 \text { 部 } \\
3 \mathrm{~kg} \text { ま }\end{array}$ & $\begin{array}{l}15 \sim 19 \text { 部 } \\
4 \mathrm{~kg} \text { まで }\end{array}$ \\
\hline \multirow[b]{2}{*}{ 第 1 地帯 } & 東京都 23 区内 & 400 円 & 460 円 & 520 円 & 580 円 \\
\hline & $\begin{array}{l}\text { 東京都下, 山形, 宮城, 福島, 杤木, 茨城, 群馬, } \\
\text { 埼玉, 千葉, 神奈川, 新潟, 長野, 山梨, 静岡, } \\
\text { 富山, 石川, 岐阜, 愛知, 滋賀, 三重 }\end{array}$ & 500 円 & 580 円 & 660 円 & 740 円 \\
\hline 第 2 地帯 & $\begin{array}{l}\text { 青森, 岩手, 秋田, 福井, 京都, 奈良, 兵庫, 大阪, } \\
\text { 和歌山, 鳥取, 島根, 岡山, 広島, 四国 } 4 \text { 県 }\end{array}$ & 650 円 & 730 円 & 810 円 & 890 円 \\
\hline 第 3 地帯 & 北海道, 山口, 九州 7 県, 沖繩 & 800 円 & 880 円 & 960 円 & 1,040円 \\
\hline
\end{tabular}

106 東京都港区麻布台 2-2-12 三貴ビル内 有機合成化学協会 合本用ファイル係 